\title{
Assessing the health impacts of peatland fires: a case study for Central Kalimantan, Indonesia
}

\author{
Saritha Kittie Uda ${ }^{1,2}$ (D) $\cdot$ Lars Hein $^{1} \cdot$ Dwi Atmoko $^{3}$ \\ Received: 19 November 2018 / Accepted: 16 August 2019 / Published online: 30 August 2019 \\ (C) The Author(s) 2019
}

\begin{abstract}
The conversion of Indonesian tropical peatlands has been associated with the recurring problems of peatland fires and smoke affecting humans and the environment. Yet, the local government and public in the affected areas have paid little attention to the impacts and costs of the poor air quality on human health. This study aims to analyse the long-term health impacts of the peat smoke exposure to the local populations. We applied the Hybrid Single-Particle Lagrangian Integrated Trajectory (HYSPLIT) model to determine the smoke dispersion and the associated $\mathrm{PM}_{2.5}$ concentrations of the resulted plumes from the fire hotspots in the deep and shallow peatlands in Central Kalimantan, Indonesia, that occurred during a 5-year period (2011-2015). We subsequently quantified the long-term health impacts of $\mathrm{PM}_{2.5}$ on the local people down to the village level based on the human health risk assessment approach. Our study shows that the average increase in the annual mean $\mathrm{PM}_{2.5}$ concentration due to peatland fires in Central Kalimantan was $26 \mu \mathrm{g} / \mathrm{m}^{3}$ which is more than twice the recommended value of the World Health Organisation Air Quality Guidelines. This increase in $\mathrm{PM}_{2.5}$ leads to increased occurrence of a range of air pollution-related diseases and premature mortality. The number of premature mortality cases can be estimated at 648 cases per year (26 mortality cases per 100,000 population) among others due to chronic respiratory, cardiovascular and lung cancer. Our results shed further light on the long-term health impacts of peatland fires in Indonesia and the importance of sustainable peatland management.
\end{abstract}

Keywords Tropical peatland fires $\cdot$ Smoke dispersion $\cdot \mathrm{PM}_{2.5}$ concentration $\cdot$ Indonesia $\cdot$ Human health impacts

Responsible editor: Philippe Garrigues

Saritha Kittie Uda

saritha.uda@wur.nl; sarithauda@fkip.upr.ac.id

Lars Hein

lars.hein@wur.nl

Dwi Atmoko

dwi.atmoko@bmkg.go.id

1 Environmental Systems Analysis Group, Wageningen University \& Research, Droevendaalsesteeg 3, 6708

PB Wageningen, The Netherlands

2 Biology Study Program, University of Palangka Raya, Jl. Yos Sudarso, Palangka Raya, Central Kalimantan 73111A, Indonesia

3 Indonesian Agency for Meteorological Climatological and Geophysics, Badan Meteorologi Klimatologi dan Geofisika (BMKG), Jl. Angkasa I No.2 Kemayoran, Jakarta Pusat, DKI, Jakarta 10720, Indonesia

\section{Introduction}

Smoke from peatland fires is a significant air pollution source associated with harmful impacts on human health and the environment. In Indonesia, peatland fires are mostly anthropogenic that may be started by farmers as part of small-scale land clearing activities, and by private companies to prepare for plantation establishment (Miettinen et al. 2017; Uda et al. 2017; Atwood et al. 2016; Turetsky et al. 2015; Marlier et al. 2015). In particular in the dry season, peat fires are difficult to control and may spread well beyond the area of ignition. Because of incomplete burning, peatland fires strongly contribute to emission of smoke haze pollutants, which contain a mixture of (fine and coarse) particulate matters or roots and various toxic and non-toxic gases (Stockwell et al. 2016). During the peatland fire episodes, in particular during the dry seasons in El Niño years, smoke covers major parts of Indonesia and even neighbouring countries (Tacconi 2016; Crippa et al. 2016). This results in negative impacts on people's health and imposes substantial costs to society. Reported impacts include general negative health effects; disruption on 
transportation (flights, road trips) and tourism business; reduced enjoyment and quality of life; increased production of ozone, acid rain, and greenhouse gases; biodiversity loss; and reduced photosynthesis in plants because of the blocked solar radiation (Benjamin et al. 2017; World Bank 2016; Koplitz et al. 2016; Hirano et al. 2012).

To further specify the impacts of peat fires, in the El Niño year of 2015 approximately 4.6 million hectares were burned, with $37 \%$ located on peatland areas, and half of the total burned area was in Kalimantan (Lohberger et al. 2018). During the period August-November 2015, many parts of Indonesia, particularly in Kalimantan and Sumatra, were reported to be heavily blanked in thick smoke (Stockwell et al. 2016). The average daily $\mathrm{CO}_{2}$ emissions over the Maritime southeast Asia region (including Indonesia, Malaysia, Singapore) during the 2015 Indonesia forest and peatland fires (biomass burning) reached $11.3 \mathrm{TgCO}_{2}$. This figure surpassed the daily release of $\mathrm{CO}_{2}$ from fossil fuel burning in the European Union (8.9 $\mathrm{Tg} \mathrm{CO}_{2}$ per day) (Huijnen et al. 2016). The fires also led to very high atmospheric particulate matter (PM) concentrations. For instance, in Central Kalimantan province, the Pollutant Standards Index (PSI) of fine particulate matter $\left(\mathrm{PM}_{2.5}\right)$ had been reported to exceed $1500\left(\mathrm{PM}_{2.5}>\right.$ $1250 \mu \mathrm{g} / \mathrm{m}^{3}$ ), considerably above short-term exposure levels considered hazardous for human health (PSI > 300, $\mathrm{PM}_{2.5}>$ $250 \mu \mathrm{g} / \mathrm{m}^{3}$ ) (Atwood et al. 2016). The health effects of the inhalable PM both in short-term and long-term are well documented which include respiratory and cardiovascular morbidity (e.g. aggravation of asthma, respiratory symptoms and an increase in hospital admissions) and mortality from cardiovascular and respiratory diseases and from lung cancer (WHO 2013).

Indonesia lacks real-time and regional air quality data due to the absence of an integrated air quality monitoring network. The air quality monitoring stations are sparse which results in insufficient data about high-risk air pollution exposures, thereby limiting the assessment of the severity of the fire-related air pollution episodes. Although the air quality conditions and the associated public health outcomes (e.g. mortality) of Indonesian forest and peatland fires have been estimated (e.g. Koplitz et al. 2016; Crippa et al. 2016; Ruchi and Rajasekhar 2017), there is still a lack of information about the potential short- and long-term related diseases at the local scale in this country (Carmenta et al. 2017). Consequently, local governments and communities in the affected areas have paid little attention to the impacts and costs of the poor air quality on the human health and environment that are caused by the mentioned annual peatland fires (Sumarga 2017; Uda et al. 2018).

This study aims to estimate the human health outcomes of the long-term exposure to peat smoke in the province of Central Kalimantan. The results can inform policymakers and stakeholders (including peatland users) on the urgency of tackling (recurrence) peatland fires and also help to increase public awareness on the importance of healthy air quality. We considered peatland fire evidences from Central Kalimantan during a 5-year period (2011, 2012, 2013, 2014 and 2015) and conducted a literature review and spatial analysis to analyse the smoke dispersion in order to estimate the annual $\mathrm{PM}_{2.5}$ concentrations of the peatland fires from the deep and shallow peatland areas. We assume that the conditions during this 5year period are representative of the long-term conditions. Subsequently, we assess long-term effects of $\mathrm{PM}_{2.5}$ exposure to local people's health based on the average concentration in these 5 years, assuming that this period, which includes one $\mathrm{El}$ Nino year, is representative for people's long-term exposure.

\section{Material and methods}

\section{Study area}

Indonesia has about 14.9 million hectares of tropical peatlands (about $8 \%$ of its total land area) that are mainly distributed across the regions of Sumatra, Kalimantan and Papua. This study specifically focuses on Central Kalimantan Province, Indonesia (see Fig. 1), which comprises about $56 \%$ of the total peatland area of the Kalimantan island and about $18 \%$ of the total Indonesia peatlands (Ritung et al. 2011). Central Kalimantan is the third largest province in Indonesia, located between latitudes $0^{\circ} 45^{\prime}$ North and $3^{\circ} 30^{\prime}$ South, and longitudes $110^{\circ} 45^{\prime}-115^{\circ} 51^{\prime}$ East, with a total area of $153,564 \mathrm{~km}^{2}$. It has about 2.7 million hectares of peatland areas (about 18\% of the total Central Kalimantan Province area), of which 59\% is deep peatlands (over 3-m deep). Central Kalimantan Province covers 14 regencies (about 1569 villages), with a population of approximately 2.5 million people (BPS Central Kalimantan 2016). Central Kalimantan has approximately 13 million hectares of forest areas (INCAS 2016). However, over the past 20 years, the forest and peatland areas in this province have been converted extensively due to land use changes and annual fires from land clearing which have been contributing significantly to the total greenhouse emissions in Indonesia (Miettinen et al. 2016; Sumarga 2017).

\section{Analysis of smoke dispersion and associated $\mathbf{P M}_{2.5}$ concentration of peat smoke}

To estimate the long-term health effects of peat smoke, we first calculated the increase in annual concentration of $\mathrm{PM}_{2.5}$ resulting from peat fire hotspots in Central Kalimantan peatland areas during 2011-2015. We assumed that the 5year period of 2011-2015 (that includes one El Niño year) is representative for the long-term concentration and exposure of peat smoke on the people living in the areas. We randomly selected 200 fire hotspots each year (100 in deep and 100 in 


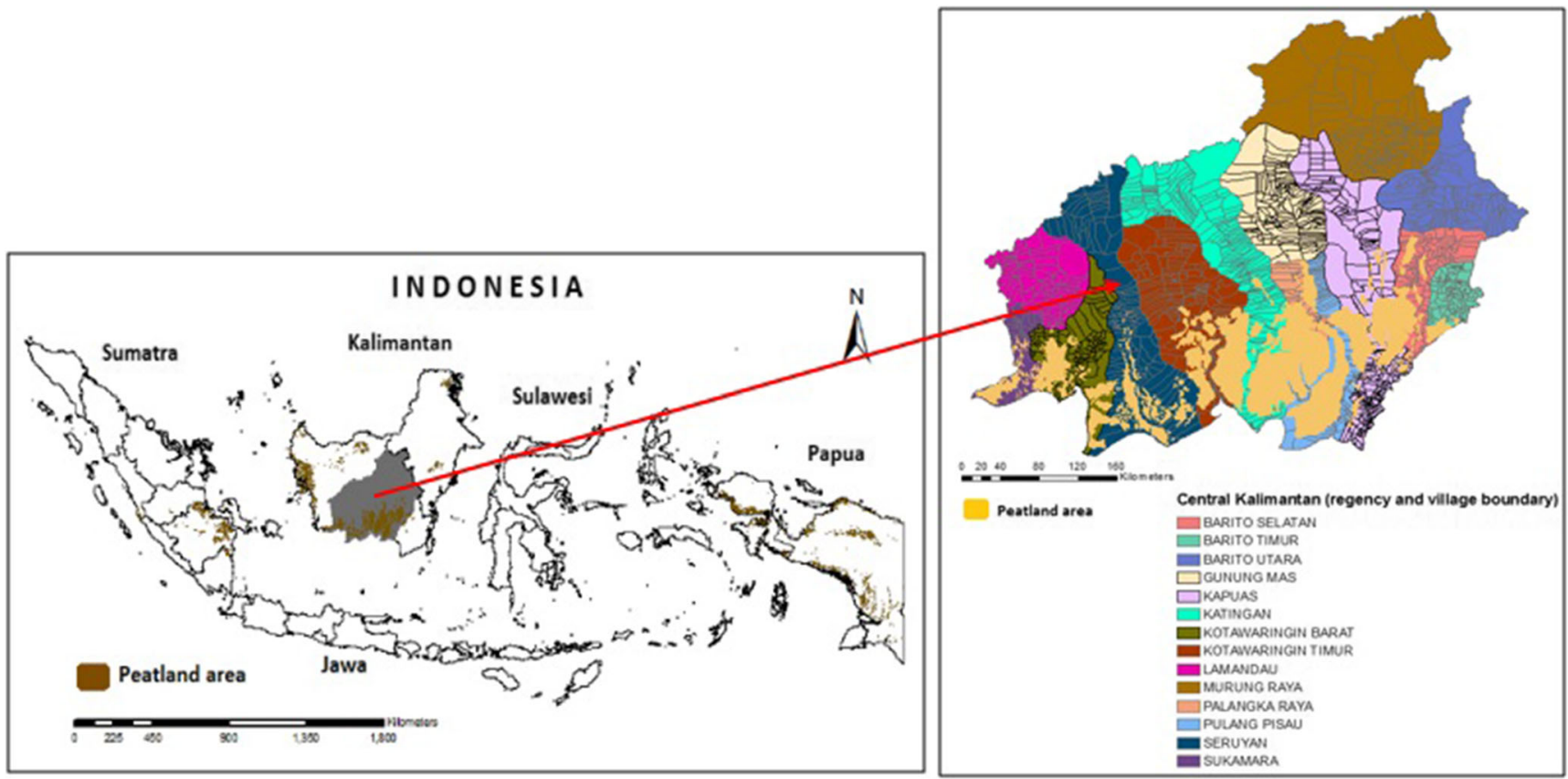

Fig. 1 Indonesian peatland distribution map (Ritung et al. 2011); Central Kalimantan province as the study area is in grey, covering 14 regencies

shallow peat) that occurred in the peatlands located in Central Kalimantan, and subsequently we used the processed data as input for the smoke dispersion model that was used to analyse the associated $\mathrm{PM}_{2.5}$ concentration. Fire hotspots are identified with the MODIS Aqua/Terra sensor, and smoke plumes were aggregated to obtain a map depicting the distribution of smoke over Central Kalimantan. We scaled up the smoke concentration by multiplying the found, averaged, smoke concentration caused by a peat fire by the number of hotspots occurring in shallow respectively deep peat in a given year, and further calibrated the model to the Palangka Raya air quality monitoring site (there is only one air quality measurement station in Central Kalimantan, which provides daily estimates of $\mathrm{PM}_{2.5}$ concentrations). We combined this with information on population density and thereby local exposures to $\mathrm{PM}_{2.5}$, and subsequently estimated the long-term health effects for the local populations on village-based analysis.

In order to generate a Central Kalimantan peatland map, we overlaid the Indonesia Peatland Map Scale 1:250,000, produced by Balai Besar Sumber Daya Lahan Pertanian (BBSDLP), the Ministry of Agriculture Republic Indonesia (Ritung et al. 2011), with the Central Kalimantan Land Cover Map, produced by the Ministry of Forestry Republic Indonesia (MoFRI 2014). Next, we overlaid the aforementioned result with the burned area and the hotspot datasets from 2011 to 2015 (containing information about latitude and longitude coordinates, date and time, confidence values; obtained from the MODIS Aqua/Terra satellites) that was obtained from the Sipongi output programs by Ministry of Environment and Forestry Republic Indonesia (MoEFRI 2015) and the Lembaga Penerbangan dan Antariksa
Nasional/LAPAN (The Indonesian National Institute of Aeronautics and Space 2015). The hotspots indicate the temperatures in a specific sensor element above a certain threshold that are defined as active fire events (burning material on the surface). Here, the MODIS sensor defines a hotspot as a detected temperature above $47{ }^{\circ} \mathrm{C}$ located within a spatial resolution of about $1 \mathrm{~km}^{2}$ (Giglio 2015; MoEFRI 2015). We only constrained the data with a confidence degree of hotspot equal to $80-100 \%$ corresponding to the high likelihood of real fires (in line with Giglio 2015; The Indonesian National Institute of Aeronautics and Space 2015). Based on this result, we then analysed the distribution of the hotspots in the deep and shallow peatland areas in Central Kalimantan. In total, there are about $3155,3604,1246,7454$ and 21,408 hotspots in peatland areas that were recorded during the year of 2011, 2012, 2013, 2014 and 2015 respectively. For the purpose of this study, it is impossible to analyse all of these hotspots, so we analysed 200 randomly selected hotspots each year and we analysed and averaged them to define an 'average' smoke plumes of a peat fire hotspot in a given year. Of the selected 200 hotspots, 100 hotspots were selected to occur in shallow peatlands and 100 hotspots in deep peatlands. We followed code of peat depth by Ritung et al. (2011) to distinguish these hotspots in the peatlands, i.e. codes of D1 and D2 are for the shallow peatlands (50-200-cm peat depth) and codes of D3 and D4 are for the deep peatlands (> 200-cm peat depth). The monthly hotspot data were extracted, and those with confidence degree $\geq 80$ were then selected and overlaid on the peat map.

Next, we applied the Hybrid Single-Particle Lagrangian Integrated Trajectory model (HYSPLIT version 4.9) to 
determine the atmospheric dispersions and plume trajectory as well as the $\mathrm{PM}_{2.5}$ concentration produced by each selected hotspot. With the HYSPLIT model, we estimated the spatial and temporal evolution of $\mathrm{PM}_{2.5}$ from a prescribed burn using the location and the burned area as inputs (Stein et al. 2015). The Global Data Assimilation System (GDAS) with a horizontal resolution of $0.5^{\circ}$ was used as the meteorological and emission data input. GDAS is daily archive files that contain global 3-dimensional gridded meteorological model output. The files contain 3-hourly data, at a half-degree latitude by half-degree longitude with resolution $720 \times 361$ grid points, on 55 hybrid sigma-pressure surfaces. Here, the HYSPLIT model does not take into account the effect of the following: chemical reactions; dense gases; byproducts from fires, explosions, or chemical reactions; complex terrain-other than what is resolved by the meteorological model's terrain (see https://ready.arl.noaa.gov/hypub/limitations.html). We also applied several assumptions in the HYSPLIT modelling for the runtime and deposition parameters. This included 24 hours for the total duration of transported pollutant material downwind (mostly peatland fires in Central Kalimantan were more than 24 hours), 24 hours for the pollutant averaging period (output interval of concentration released), $100 \mathrm{~m}$ AGL (above-ground-level) for the top averaged plume's layer (100 m AGL is the minimum height to adequately represent the plume and indicate the concentration), and deposition parameters for the dry deposition rate $(0.001 \mathrm{~m} / \mathrm{s})$ and for the wet deposition rate (8.0E-05 litter/s). The output of the HYSPLIT model shows the dispersion within the direction of the plumes, with the range concentrations of $\mathrm{PM}_{2.5}$ (including the maximum and minimum concentrations).

We then aggregated all the plumes of "observed hotspots" resulting from the HYSPLIT model and adjusted the resulting $\mathrm{PM}_{2.5}$ concentrations by calibrating them with the annual average concentration of $\mathrm{PM}_{2.5}$ in Palangka Raya City for the total amount of hotspots in peatland areas during 2011-2015. We used these average concentrations of $\mathrm{PM}_{2.5}$ to estimate the annual concentration of $\mathrm{PM}_{2.5}$ of all observed hotspots in a given year. The resulting $\mathrm{PM}_{2.5}$ concentrations were aggregated (spatially) in order to produce a map of annual mean concentration of $\mathrm{PM}_{2.5}$ for a 5-year period (2011-2015). The ground-based observation data used for the calibration was taken from the Air Quality Monitoring System/AQMS (or Indeks Standar Pencemaran Udara/ISPU), published by the Environmental Agency (Badan Lingkungan Hidup Daerah/ BLHD) of Palangka Raya City, Central Kalimantan, and Badan Meteorologi Klimatologi dan Geofisika/BMKG (the Indonesian Agency for Meteorological Climatological and Geophysics). By using the Central Kalimantan administration map (published by Central Kalimantan Statistical Bureau), we spatially quantified the annual average concentration of $\mathrm{PM}_{2.5}$ in every village based on the village boundaries. We subsequently used this output to assess the exposure of people to $\mathrm{PM}_{2.5}$ on a village-based analysis as described in the next step. All spatial analyses were implemented using ArcGIS 10.5 at a spatial resolution of $1-\mathrm{km}^{2}$ grid cell and with the output coordinate system of WGS 1984 UTM Zone 49S. All of the HYSPLIT models were done using NOAA ARL (Air Resources Laboratory NOAA) software (Stein et al. 2015).

\section{Analysis of the long-term human health impacts of the $\mathrm{PM}_{2.5}$ exposure}

In order to analyse the mortality impacts of $\mathrm{PM}_{2.5}$ exposure resulting from the peat smoke, we quantified the health impacts (number of premature mortality cases including total mortality and mortality due to different diseases) in the receptors (inhabitants) in each village. We applied a human health risk assessment based on Ostro (2004), Burnett et al. (2014), Crippa et al. (2016) and Koplitz et al. (2016). We calculated the relative risk $(\mathrm{RR})$ and the attributable fraction (AF or impact fraction, IF) of premature mortality for three types of the health case categories, i.e. cardiovascular, lung cancer and chronic respiratory diseases due to long-term exposure to $\mathrm{PM}_{2.5}$ (Crippa et al. 2016). We applied the log-linear exposure formula for the relative risk function as $\mathrm{RR}=\left[(X+1) /\left(X_{o}+\right.\right.$ $1)]^{\beta}$ for $X \geq X_{o}$, where $X$ refers to the average of the annual mean concentration of $\mathrm{PM}_{2.5}$ (in $\mu \mathrm{g} / \mathrm{m}^{3}$ ), during the period of observation. $X_{o}$ is the lowest observed concentration from the average of annual mean of $\mathrm{PM}_{2.5}$ concentration $\left(\mu \mathrm{g} / \mathrm{m}^{3}\right.$, as the lowest effect level) and $\beta$ is the excess mortality per-unit increase in $\mathrm{PM}_{2.5}$ with suggested $\beta$ coefficients of 0.1551 , $0.23218,0.003794$ and 0.001829 for measuring cardiovascular case, lung cancer case, chronic respiratory case and premature mortality, respectively (Ostro 2004). For the purpose of this study, we renormalize the suggested $\beta$ coefficient for allcause of mortality (0.0008) and chronic respiratory case due to $\mathrm{PM}_{10}$ exposure $(0.00166)$ by multiplying the coefficient with the Indonesia conversion factor $48 / 21\left(\mathrm{PM}_{10} / \mathrm{PM}_{2.5}\right.$ ratio) (WHO 2014). Next, we calculated the attributable fraction by using $\mathrm{AF}$ function as $\mathrm{AF}_{\mathrm{d}}=\mathrm{RR}_{\mathrm{d}}(X)-\mathrm{RR}_{\mathrm{d}}\left(X_{o}\right)$ where $R_{d}$ is relative risk of disease (Crippa et al. 2016). The total number of mortality cases due to long-term exposure of $\mathrm{PM}_{2.5}$ from peatland fires and smoke in the study area were calculated by multiplying the attributable fraction (AF) with the baseline mortality risk of the related health case and the number of population in the study area (Ostro 2004; Koplitz et al. 2016; Crippa et al. 2016). 
It is noted that in this study, the baseline mortality rate is based on the overall death rate (CDR) for Central Kalimantan in 2015 which was 5.8 per 1000 population of all ages (BPS Central Kalimantan 2017), reflecting a still growing population. We used village-based data for year 2015 provided by the Central Kalimantan Statistical Bureau (BPS Central Kalimantan 2016) which were supplemented with the health data (e.g. number of live birth, number of registered patients) from the Central Kalimantan Health Department (Dinas Kesehatan Provinsi Kalimantan Tengah 2016; The Indonesian Ministry of Health 2016). We calculated the number of deaths in each village by multiplying the value of the death rate 0.0058 with the total population of each village. We then defined the number of mortality for each health case by multiplying the total number of deaths in each village with the percentage of deaths for the related health case categories obtained from IHME-GHDx Data 2017 (IHME-GHDx 2018). Specifically for Central Kalimantan, the percent of deaths in 2015 for all ages are 33\%, 4\% and 2\% for the related health case categories of cardiovascular, chronic respiratory and lung cancer, respectively. The performance health case categories, the percent of deaths, the relative risk functions and the age group and its fraction values are described in Table 1 . A sensitivity analysis was conducted by changing the relative risk function as linear exposure formula, i.e. $\mathrm{RR}=\exp \left[\beta\left(\mathrm{X}-\mathrm{X}_{\mathrm{o}}\right)\right]$ as well as varying $X$ (the decreasing and increasing) by $10 \mu \mathrm{g} / \mathrm{m}^{3}$ and $X_{o}$ at $10 \mu \mathrm{g} / \mathrm{m}^{3}$ (the lowest level according to WHO 2016).

\section{Results}

\section{Smoke dispersion and associated $\mathrm{PM}_{2.5}$ concentrations from the peat smoke}

Based on our spatial analysis, the average of annual mean concentration of $\mathrm{PM}_{2.5}$ from the smokes due to peatland fires in Central Kalimantan in the period 2011-2015 was $26 \mu \mathrm{g} / \mathrm{m}^{3}$ (ranging from 4 to $103 \mu \mathrm{g} / \mathrm{m}^{3}$ on the village-based analysis). This is more than twice the recommended WHO AQG annual mean for $\mathrm{PM}_{2.5}$ concentration exposure limit which is $10 \mu \mathrm{g} /$ $\mathrm{m}^{3}$ (WHO 2006). Among all regencies in Central Kalimantan, Palangka Raya City showed the highest annual mean of PM2.5 concentrations with the average level of $38 \mu \mathrm{g} / \mathrm{m}^{3}$ (ranging from 27 to $43 \mu \mathrm{g} / \mathrm{m}^{3}$ on the village-based analysis) over the 5-year period. Notably, the average concentration of $\mathrm{PM}_{2.5}$ in Central Kalimantan for the year 2015 alone (the year with the highest peatland fire occurrence) was $48 \mu \mathrm{g} / \mathrm{m}^{3}$ (ranging from 40 to $190 \mu \mathrm{g} / \mathrm{m}^{3}$ ), while in Palangka Raya alone was $65 \mu \mathrm{g} / \mathrm{m}^{3}$ (ranging from 53 to $84 \mu \mathrm{g} / \mathrm{m}^{3}$ ). It is noted that the study by Koplitz et al. (2016) estimated the average of $\mathrm{PM}_{2.5}$ concentration across Indonesia, Malaysia and Singapore due to the 2015 fires was $\sim 60 \mu \mathrm{g} / \mathrm{m}^{3}$ (over the 2 month period September-October 2015).

Our analysis also shows that fires in both deep and shallow peatlands in Central Kalimantan are important sources of air pollution (see Appendix 1). Fires from deep and shallow peat contribute roughly the same to the annual mean increase in $\mathrm{PM}_{2.5}$ concentration, i.e. both contribute approximately 13 $\mu \mathrm{g} / \mathrm{m}^{3}$ (ranging from 2 to $131 \mu \mathrm{g} / \mathrm{m}^{3}$ for the deep peatlands, and ranging from 0.7 to $50 \mu \mathrm{g} / \mathrm{m}^{3}$ for the shallow peatlands). During the 5-year period 2011-2015 from peatland fires, 99\% of total villages (1554 of 1569 villages) showed an average annual mean $\mathrm{PM}_{2.5}$ concentration above $10 \mu \mathrm{g} / \mathrm{m}^{3}$. Among the 1569 villages in Central Kalimantan, 4 villages (all are in Kapuas regency) showed annual mean $\mathrm{PM}_{2.5}$ concentrations above $80 \mu \mathrm{g} / \mathrm{m}^{3}$ (ranging from 82 to $103 \mu \mathrm{g} / \mathrm{m}^{3}$ on the villagebased analysis). This means the 4 villages (with the total population of 5886 inhabitants) experience annual mean $\mathrm{PM}_{2.5}$ concentrations that exceed more than eight times the exposure limit of $\mathrm{PM}_{2.5}$ concentration indicated by the WHO AQGs. We have noted that some villages (including the 4 villages with the annual mean $\mathrm{PM}_{2.5}$ concentrations above $80 \mu \mathrm{g} / \mathrm{m}^{3}$ ) are also located in ex-Mega Rice Project's area with intensive

Table 1 The potential health case categories, percent of deaths, age groups and fraction values, and relative risk function to $\mathrm{PM}_{2.5}$

\begin{tabular}{|c|c|c|c|}
\hline Health case categories & $\begin{array}{l}\text { Percent of deaths from } \\
\text { exposure to } \mathrm{PM}_{2.5} \text { for all ages }(\%)^{\mathrm{a}}\end{array}$ & $\begin{array}{l}\text { RR function and } \beta \\
\text { coefficient for } \mathrm{PM}_{2.5} \mathrm{~b}\end{array}$ & $\begin{array}{l}\text { Age group and } \\
\text { fraction }(\%)\end{array}$ \\
\hline Premature mortality (all-cause) ${ }^{\mathrm{c}}$ & 100 & Linear exposure; 0.001829 & All ages $(100 \%)$ \\
\hline Chronic respiratory $^{\mathrm{c}}$ & 4 & Linear exposure; 0.003794 & Children $<5$ years $(10 \%)$ \\
\hline Cardiovascular & 33 & Log-linear exposure; 0.15515 & Adults 30 and above $(44.5 \%)$ \\
\hline Lung cancer & 2 & Log-linear exposure; 0.23218 & Adults 30 and above $(44.5 \%)$ \\
\hline
\end{tabular}

a The percent of deaths in 2015 for all ages in Central Kalimantan based on IHME-GHDx (2018)

$\mathrm{b}$ The suggested $\beta$ coefficients are based on Ostro (2004)

${ }^{\mathrm{c}}$ We renormalize the suggested $\beta$ coefficient of $\mathrm{PM}_{10}$ by multiplying with the Indonesia conversion factor $48 / 21\left(\mathrm{PM}_{10} / \mathrm{PM}_{2.5}\right.$ ratio) $\left(\mathrm{WHO}_{2014}\right)$ 


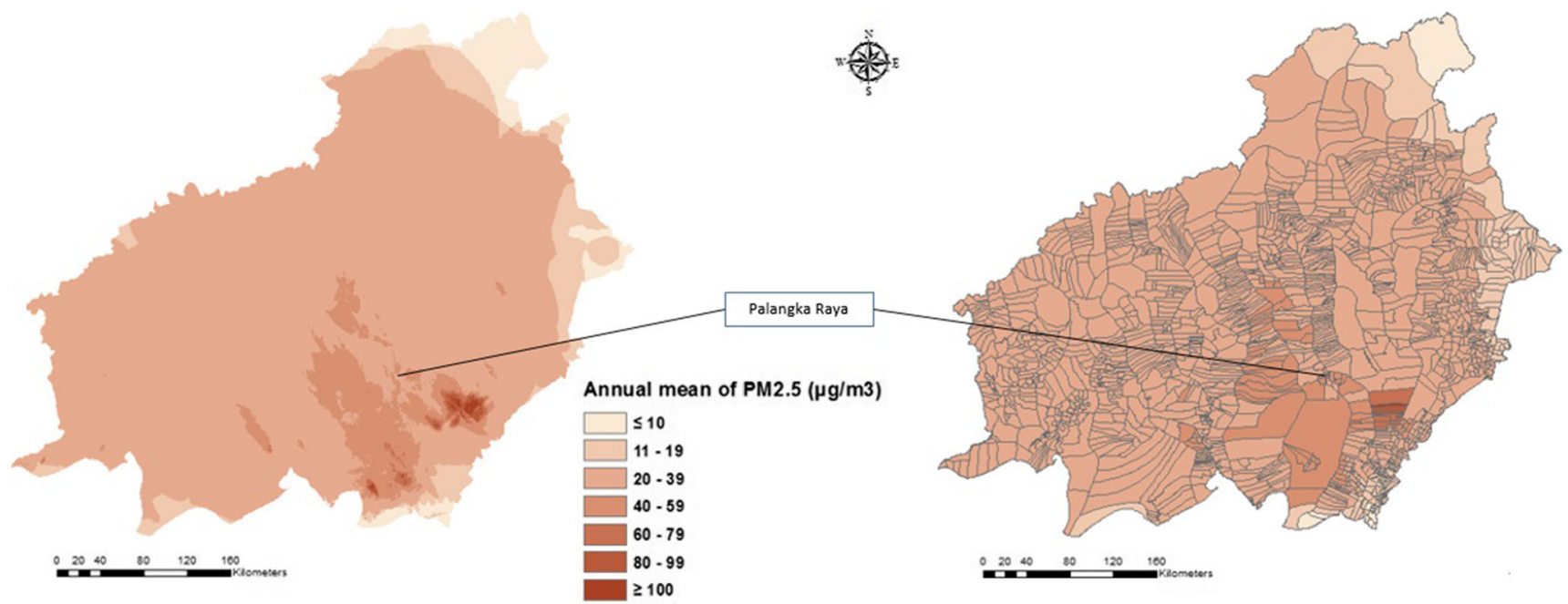

Fig. 2 Smoke dispersion and associated average increase in annual mean $\mathrm{PM}_{2.5}$ concentrations $\left(\mu \mathrm{g} / \mathrm{m}^{3}\right)$ in Central Kalimantan, Indonesia, from hotspots in peatlands during a 5-year period (2011-2015); the right-hand map is based on 1569 village boundaries

peatland utilisations over the last decade. In Central Kalimantan during 2011-2015, the total number of hotspots that occurred in deep peatlands was $8 \%$ greater than that occurred in shallow peatlands - hence, both shallow and deep peatlands contribute substantially to the health effects resulting from peat fires.

Figure 2 displays the distribution of the annual mean value of $\mathrm{PM}_{2.5}$ concentration based on village boundaries in Central Kalimantan from one aggregated plumes of hotspots located in the peatland areas. Our spatial analysis revealed that only $1 \%$ of total villages (15 of 1569 villages) in Central Kalimantan showed low $\mathrm{PM}_{2.5}$ concentrations (less than 10 $\mu \mathrm{g} / \mathrm{m}^{3}$ ) in accordance with the exposure limit for $\mathrm{PM}_{2.5}$ suggested by WHO AQG. More concerning, about $78 \%$ of total villages in Central Kalimantan (1230 of 1569) experience $\mathrm{PM}_{2.5}$ exposures with annual average $\mathrm{PM}_{2.5}$ concentrations $\geq 20 \mu \mathrm{g} / \mathrm{m}^{3}$. This means that about 2 million inhabitants (about $80 \%$ of the total population in Central Kalimantan), including more than 430 thousand children aged 5 to 14 years, 65 thousand infants aged between 0 and 1 year, and over 1.4 million adult people aged 27 years and older, experience health impacts due to the inhalation of $\mathrm{PM}_{2.5}$.

\section{Potential human health outcomes}

Table 2 summarizes the potential health outcomes with the number of premature mortality and disease cases experienced by the local populations in Central Kalimantan due to longterm exposure to $\mathrm{PM}_{2.5}$ with an increase in annual mean $\mathrm{PM}_{2.5}$ concentration of $26 \mu \mathrm{g} / \mathrm{m}^{3}$ during 2011 to 2015 . Appendix 2 presents the sensitivity analysis for changing the relative risk function and varying $X$ and $X_{o}$ (concentrations of $\mathrm{PM}_{2.5}$ ).

Table 2 The potential health outcomes due to exposure to $\mathrm{PM}_{2.5}$ emissions from peat smoke in Central Kalimantan, Indonesia, during a 5-year period (2011-2015)

\begin{tabular}{lllll}
\hline $\begin{array}{l}\text { Health case } \\
\text { categories }\end{array}$ & $\begin{array}{l}\text { Relevant age group and number } \\
\text { of population in age group (people) }\end{array}$ & $\begin{array}{l}\text { Estimated number } \\
\text { of deaths for all ages }\end{array}$ & $\begin{array}{l}\text { Estimated number of } \\
\text { deaths due to peat smoke }\end{array}$ & $\begin{array}{l}\text { Estimated number of deaths due } \\
\text { to peat smoke per 100,000 people } \\
\text { in age group }\end{array}$ \\
\hline $\begin{array}{l}\text { Premature mortality (all-cause) } \\
\text { - of which, due to: }\end{array}$ & All ages $\left(2.5 \times 10^{6}\right)$ & 14,601 & 648 & 26 \\
Chronic respiratory & All ages $\left(2.5 \times 10^{6}\right)$ & 584 & 55 & 2 \\
& Children $<5$ years $\left(2.5 \times 10^{5}\right)$ & 58 & 6 & 2 \\
Cardiovascular & All ages $\left(2.5 \times 10^{6}\right)$ & 4818 & 266 & 11 \\
& Adults 30 and above $\left(1.1 \times 10^{6}\right)$ & 2144 & 119 & 4 \\
Lung cancer & All ages $\left(2.5 \times 10^{6}\right)$ & 292 & 95 & 4 \\
& Adults 30 and above $\left(1.1 \times 10^{6}\right)$ & 130 & 42 &
\end{tabular}


We estimate that the long-term exposure to $\mathrm{PM}_{2.5}$ from peat smoke, as estimated during a 5-year period (2011-2015), causes 648 premature mortality cases per year ( 26 mortality cases per 100,000 people). These include 55 mortality cases due to chronic respiratory diseases, 266 mortality cases from cardiovascular diseases and 95 mortality cases from lung cancer. It is noted that the mortality cases due to chronic respiratory diseases include 6 mortality cases of children aged below 5 years (this equates to 2 mortality cases per 100,000 children aged below 5 years).

Our sensitivity analysis revealed that with an increase of 10 $\mu \mathrm{g} / \mathrm{m}^{3}$ in the $\mathrm{PM}_{2.5}$ concentration, the premature mortality cases increase with $34 \%$, while the mortality cases due to chronic respiratory disease, cardiovascular diseases and lung cancer will increase with $27 \%, 108 \%$ and $15 \%$, respectively. With a decrease of $10 \mu \mathrm{g} / \mathrm{m}^{3}$ in the $\mathrm{PM}_{2.5}$ concentration, the premature mortality will decrease with $45 \%$, and the mortality due to chronic respiratory disease, cardiovascular diseases and lung cancer will decrease by $47 \%, 27 \%$ and $26 \%$, respectively. Also, the value of RR for premature mortality is ranging from 1.00 to 1.09 within the different exposure functions and background concentrations. The highest numbers of cases were in Kotawaringin Timur regency which has a relatively large population and a high exposure to smog from peat fires.

\section{Discussion}

This present study has several limitations. Uncertainties are generated from the meteorological inventory datasets and the referenced values used as inputs in the HYSPLIT model which are used in the analysis of the average concentration of $\mathrm{PM}_{2.5}$ in Central Kalimantan. We recognise that the differences in default inputs among meteorological inventory data (e.g. GDAS $1^{\circ}$, Reanalysis (NCEP/NCAR), GFAS, have different spatial resolutions) cause uncertainty related to the estimation of plume trajectory which then affects the estimation of both $\mathrm{PM}_{2.5}$ concentration and its spatial distribution (Khairullah et al. 2017; Koplitz et al. 2016; Crippa et al. 2016). In the HYSPLIT model, the plume trajectories and dispersions of $\mathrm{PM}_{2.5}$ are simulated based on the Bluesky model in which the GDAS archive is set up as default input meteorological data. The GDAS data have resulted in the enhanced data assimilation methods, having the highest horizontal, vertical and temporal resolution (Godłowska et al. 2015). Also, using a $1-\mathrm{km}^{2}$ resolution for input values might contribute to the differences in the calculated results of $\mathrm{PM}_{2.5}$ concentrations. However, a sensitivity experiment that we conducted by changing a $1-\mathrm{km}^{2}$ resolution to a $2 \times 2 \mathrm{~km}$ resolution using the same procedure as for the $1-\mathrm{km}^{2}$ model resulted in no significant changes in calculated $\mathrm{PM}_{2.5}$ concentrations. The wind directions and topography are the main factors that influence the smoke dispersion and associated distribution of $\mathrm{PM}_{2.5}$ concentrations (Khairullah et al. 2017).

Besides, in this study we did not address the smoke dispersion from the neighbouring provinces. Peat fires in adjacent provinces will also contribute to smog in Central Kalimantan. We did not consider this effect, and we are therefore underestimating the health effects from peat fires.

In relation to the health impact estimation, several uncertainties were associated with our assumptions. First, we averaged the smoke concentrations over the year to assess the health effects. However, in reality smoke has a seasonal occurrence. Most of the (thick) smoke occurred from July to November (months when the land clearing activities usually start). We are not able to indicate if taking an annual average is leading to an over- or underestimate of the mortality and morbidity assessment. Our study also assessed the average of the annual mean of $\mathrm{PM}_{2.5}$ concentration in 2011-2015 which included an El Niño period. The El Niño period (e.g. 2015) has months with an extreme reduction of precipitation and heavy fire activity and risks. Nevertheless, fires in peatland areas have occurred during non-drought years as well (see Gaveau et al. 2014). Our assumption is that the period 2011 to 2015 is representative. We cannot be sure that this is the case. However, we note that land conversion of peatlands in Central Kalimantan is still ongoing which implies that future smog may be worse than present conditions.

Second, we used the logarithm exposure function by Ostro (2004) to estimate the health impacts. The logarithm functions are recommended by WHO to estimate the health impacts in the areas with the high concentrations of air pollution (Burnett et al. 2014). However, the uncertainty on the estimation will be related to the unknown parameters such as the suggested $\beta$ coefficients for $\mathrm{PM}_{2.5}$ in this model. These parameters were estimated from the American Cancer Society (ACS) cohort studies (Ostro 2004; WHO 2006). This uncertainty can lead to different outcomes when the coefficients are not consistent with the risk model form (Burnett et al. 2014; Héroux et al. 2015). Thus, conducting proper epidemiological studies in the area is recommended in order to refine the exposure functions especially for the purpose of evaluating the impacts of episodic severe smoke from landscape fires. It is noted that we were not able to assess the morbidity impacts (such as cardiovascular diseases, lung diseases and lost working days) since the baseline data for the occurrence of such diseases is missing in Kalimantan.

Third, we calibrated our model based on air quality data available for only one city, i.e. Palangka Raya. No other data points are available in Central Kalimantan, in spite of the significant health risks related to peat fires, as indicated by our study. We therefore recommend the Government of 
Indonesia to expand the number of air quality monitoring stations in the province.

In order to assess the accuracy of our study, we compared our findings with available reported data on health impacts. The Central Kalimantan government reported (without mentioned specific data per case) that 2483 people (including 407 infants) died in 2015 (Dinas Kesehatan Provinsi Kalimantan Tengah 2016). However, causes for mortality were not specified. There were also no reports on the occurrence of air pollutionrelated diseases, even though newspaper reports in 2015 reported increases in hospital admissions (Dinas Kesehatan Provinsi Kalimantan Tengah 2016). It is noted that the Indonesia Government reported the total number of mortality cases in the whole of Indonesia due to the 2015 haze caused by forest and land fires to be 19 people, with more than 500,000 cases of acute respiratory infections (World Bank 2016). In the same report, for Central Kalimantan, the health impacts of forest and peatland fires in 2015 were reported to be only 1 mortality case and nearly 25,000 cases of upper respiratory tract infections (BNPB Indonesia 2017; The Indonesian Ministry of Health 2015). However, our study shows that this is an underestimate of the actual health impacts of fires, which is related to the government only analysing the short-term health effects of exposure to fire in a specific year. Also, the latter studies by Koplitz et al. (2016) and Crippa et al. (2016) estimated the health impacts in Indonesia by analysing a short-term period of the 2015 haze event caused by forest and land fires (September-October 2015). Koplitz et al. estimated 91,600 excess mortality for the Indonesian population aged over 25 years with the average $\mathrm{PM}_{2.5}$ concentrations of $\sim 60 \mu \mathrm{g} / \mathrm{m}^{3}$, while Crippa et al. estimated 11,880 excess all-cause premature mortalities due to short-term exposure to unhealthy air quality conditions (using simulated 24-hr $\mathrm{PM}_{2.5}$ of $56-160 \mu \mathrm{g} / \mathrm{m}^{3}$ ) and 75,600 excess all-cause premature mortalities due to long-term exposure to the $\mathrm{PM}_{2.5}$ concentrations for the overall population in Indonesia, Malaysia and Singapore (including 3223 premature mortality cases due to lung cancer in the adult population aged over 25 years). In our study, we calculate the long-term health effects of the recurrent annual exposure to smoke from the peat fires (based on average fire and smoke conditions over 2011-2015). We cannot scale up our results to the whole of Indonesia given that the smoke concentration varies considerably over the different islands, but note that Central Kalimantan has a relatively low population of only 2.5 million, only $1 \%$ of the country's population.

A range of studies show that the long-term exposure to $\mathrm{PM}_{2.5}$ is a main driver for the health effects of air pollution (e.g. see Burnett et al. 2018; Hoek et al. 2013; Pope et al. 2002; Pope and Dockery 1999). Even though the fires of 2015 were large compared with these of preceding years, also in other years the people of Central Kalimantan are exposed to smoke from peat fires. This study shows the importance of considering these long-term health effects.

\section{Conclusions}

Our study estimated the long-term health impacts of frequent exposure to high $\mathrm{PM}_{2.5}$ concentration on the human population in Central Kalimantan due to smoke and peatland fires. We model fire and smoke occurrence in the period 2011-2015 and assume that this period is representative for people's long-term exposure. We showed that the 2.5 million people in Central Kalimantan are exposed to annual mean $\mathrm{PM}_{2.5}$ concentrations, due to peat fires, that are well above the WHO AQG of $10 \mu \mathrm{g} / \mathrm{m}^{3}$. The average increase in annual mean $\mathrm{PM}_{2.5}$ concentrations due to peat fires (in shallow and deep peat) in Central Kalimantan was $26 \mu \mathrm{g} / \mathrm{m}^{3}$, of which the annual mean $\mathrm{PM}_{2.5}$ concentrations from hotspots in deep peat were $13 \mu \mathrm{g} / \mathrm{m}^{3}$ (ranging from 2 to $131 \mu \mathrm{g} / \mathrm{m}^{3}$ ) and from the shallow peat were also $13 \mu \mathrm{g} / \mathrm{m}^{3}$ (ranging from 0.7 to $50 \mu \mathrm{g} / \mathrm{m}^{3}$ ). This long-term exposure of $\mathrm{PM}_{2.5}$ from recurrent peat fires and smoke events causes 648 premature mortality cases per year which includes 55 mortality cases due to chronic respiratory diseases, 266 mortality cases due to cardiovascular diseases and 95 mortality cases due to lung cancer. This equates to 26 premature mortality cases per 100,000 people.

The assessment of long-term health impacts on the local population may help the local government and stakeholders in Central Kalimantan province to better assess the health implications of different peatland uses and to take the initiatives to set and enforce higher standards for sustainable peatland management (particularly mitigation policies on fires and drained peatland uses; and also adding air quality monitoring stations). Although the results of our study cannot be extrapolated, it still indicates that a large number of fatalities due to peat fires may occur in Indonesia at large. There are about 57 million inhabitants in Sumatra and about 16 million inhabitants in Kalimantan, and most of these are affected on an annual basis by smoke from burning peatlands. Our work confirms the high urgency of addressing the ongoing peatland conversion and degradation in Indonesia.

Acknowledgments The authors gratefully acknowledge the NOAA Air Resources Laboratory (ARL) for the provision of the HYSPLIT transport and dispersion model used in this publication. This study also benefited from the availability of hotspot, land cover, burned area, peatland area and other spatial data provided by the Indonesian Ministry of Environment and Forestry (MoEFRI), the Indonesian National Institute of Aeronautics and Space (Lembaga Penerbangan dan Antariksa Nasional/LAPAN) and the Indonesian Agency for Meteorological Climatological and Geophysics (Badan Meteorologi Klimatologi dan Geofisika/BMKG). We also sincerely acknowledge the Governor of Central Kalimantan Province for giving permission to access the relevant data in Central Kalimantan provincial institutions. The first author gratefully acknowledges the Lembaga Pengelola Dana Pendidikan/LPDP (Indonesia Endowment Fund for Education) for providing a scholarship for this study. The authors would like to thank the reviewers for their helpful comments. 


\section{Appendix 1}

(a) From hotspots in deep peatland areas

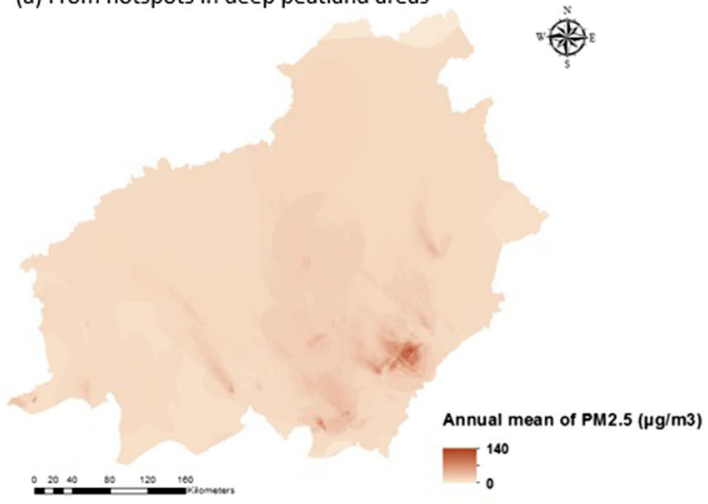

(b) From hotspots in shallow peatland areas

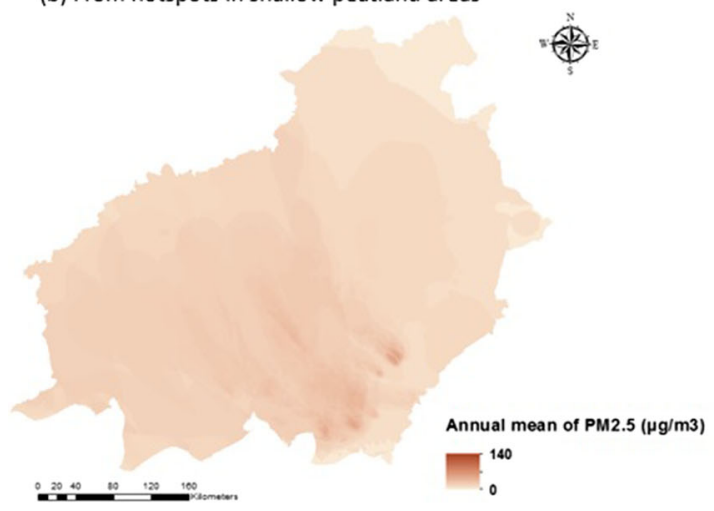

(c) From hotspots in deep and shallow peatland areas

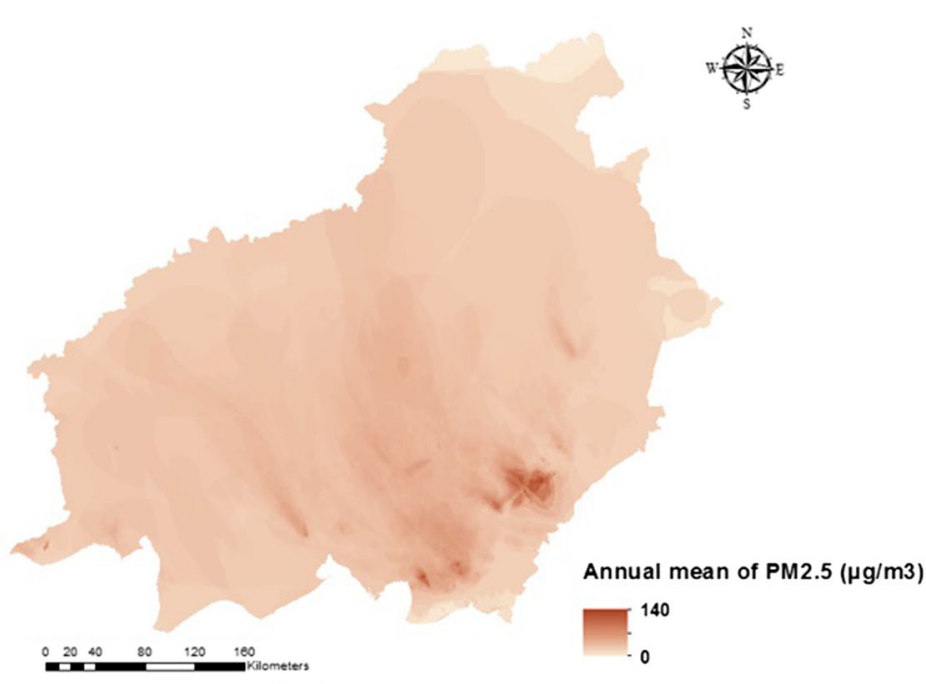

Fig. 3 Smoke dispersion and associated annual average concentration of $\mathrm{PM}_{25}\left(\mu \mathrm{g} / \mathrm{m}^{3}\right)$ in Central Kalimantan, Indonesia, from hotspots $2011-2015$ in (a) deep peatland areas; (b) shallow peatland areas; (c) deep and shallow peatland areas combined 


\section{Appendix 2}

Table 3 The health impacts due to exposure to $\mathrm{PM}_{2.5}$ emissions from peat smoke in Central Kalimantan, Indonesia, during a 5-year period (20112015) (sensitivity analysis, showing impacts of $10 \mu \mathrm{g} / \mathrm{m}^{3}$ increase and decrease in $\mathrm{PM}_{2.5}$ concentrations, as well as double the $\mathrm{PM}_{2.5}$ concentration)

\begin{tabular}{|c|c|c|c|c|}
\hline Health case categories & $\begin{array}{l}X^{\mathrm{a}} \\
\left(\mu \mathrm{g} / \mathrm{m}^{3} \mathrm{PM}_{2.5}\right)\end{array}$ & $\begin{array}{l}X_{o}^{\mathrm{a}} \\
\left(\mu \mathrm{g} / \mathrm{m}^{3} \mathrm{PM}_{2.5}\right)\end{array}$ & $\begin{array}{l}\text { Shape of exposure function, } \\
R R \text { and attributable fraction for } \mathrm{PM}_{2.5}\end{array}$ & $\begin{array}{l}\text { Number of deaths from } \\
\text { exposure to } \mathrm{PM}_{2.5} \text { for all ages }\end{array}$ \\
\hline \multirow[t]{14}{*}{ Premature mortality (all-cause) } & 26 & 4 & Linear; $1.04 ; 0.04$ & 648 \\
\hline & 26 & 5.8 & Linear; $1.04 ; 0.04$ & 598 \\
\hline & 26 & 8 & Linear; $1.03 ; 0.03$ & 514 \\
\hline & 26 & 10 & Linear; $1.03 ; 0.03$ & 463 \\
\hline & 36 & 4 & Linear; $1.06 ; 0.06$ & 871 \\
\hline & 16 & 4 & Linear; $1.02 ; 0.02$ & 359 \\
\hline & 52 & 4 & Linear; $1.09 ; 0.09$ & 1303 \\
\hline & 26 & 4 & Log-linear; $1.00 ; 0.003$ & 46 \\
\hline & 26 & 5.8 & Log-linear; $1.00 ; 0.002$ & 37 \\
\hline & 26 & 8 & Log-linear; $1.00 ; 0.002$ & 30 \\
\hline & 26 & 10 & Log-linear; $1.00 ; 0.002$ & 25 \\
\hline & 36 & 4 & Log-linear; $1.00 ; 0.004$ & 54 \\
\hline & 16 & 4 & Log-linear; $1.00 ; 0.002$ & 32 \\
\hline & 52 & 4 & Log-linear; $1.00 ; 0.004$ & 63 \\
\hline \multirow[t]{14}{*}{ Chronic respiratory } & 26 & 4 & Linear; $1.09 ; 0.09$ & 55 \\
\hline & 26 & 5.8 & Linear; $1.08 ; 0.08$ & 51 \\
\hline & 26 & 8 & Linear; $1.07 ; 0.07$ & 42 \\
\hline & 26 & 10 & Linear; $1.06 ; 0.06$ & 38 \\
\hline & 36 & 4 & Linear; $1.13 ; 0.12$ & 70 \\
\hline & 16 & 4 & Linear; $1.05 ; 0.05$ & 29 \\
\hline & 52 & 4 & Linear; $1.21 ; 0.17$ & 102 \\
\hline & 26 & 4 & Log-linear; $1.01 ; 0.01$ & 4 \\
\hline & 26 & 5.8 & Log-linear; $1.01 ; 0.01$ & 3 \\
\hline & 26 & 8 & Log-linear; $1.00 ; 0.004$ & 2 \\
\hline & 26 & 10 & Log-linear; $1.00 ; 0.003$ & 2 \\
\hline & 36 & 4 & Log-linear; $1.01 ; 0.01$ & 4 \\
\hline & 16 & 4 & Log-linear; $1.00 ; 0.004$ & 3 \\
\hline & 52 & 4 & Log-linear; 1.01; 0.01 & 5 \\
\hline \multirow{14}{*}{ Cardiovascular ${ }^{\mathrm{b}}$} & 26 & 4 & Linear; $1.23 ; 0.23$ & 1151 \\
\hline & 26 & 5.8 & Linear; $1.21 ; 0.21$ & 1056 \\
\hline & 26 & 8 & Linear; 1.18; 0.15 & 766 \\
\hline & 26 & 10 & Linear; $1.16 ; 0.13$ & 693 \\
\hline & 36 & 4 & Linear; $1.34 ; 0.25$ & 1242 \\
\hline & 16 & 4 & Linear; 1.12; 0.1 & 543 \\
\hline & 52 & 4 & Linear; $1.57 ; 0.35$ & 1741 \\
\hline & 26 & 4 & Log-linear; $1.3 ; 0.05$ & 266 \\
\hline & 26 & 5.8 & Log-linear; $1.24 ; 0.08$ & 386 \\
\hline & 26 & 8 & Log-linear; $1.18 ; 0.15$ & 765 \\
\hline & 26 & 10 & Log-linear; $1.15 ; 0.13$ & 637 \\
\hline & 36 & 4 & Log-linear; $1.36 ; 0.11$ & 553 \\
\hline & 16 & 4 & Log-linear; $1.2 ; 0.04$ & 194 \\
\hline & 52 & 4 & Log-linear; $1.44 ; 0.19$ & 930 \\
\hline \multirow[t]{12}{*}{ Lung cancer $^{\mathrm{b}}$} & 26 & 4 & Linear; $1.34 ; 0.34$ & 104 \\
\hline & 26 & 5.8 & Linear; $1.31 ; 0.31$ & 95 \\
\hline & 26 & 8 & Linear; $1.27 ; 0.2$ & 63 \\
\hline & 26 & 10 & Linear; $1.24 ; 0.18$ & 57 \\
\hline & 36 & 4 & Linear; $1.52 ; 0.33$ & 100 \\
\hline & 16 & 4 & Linear; $1.18 ; 0.14$ & 45 \\
\hline & 52 & 4 & Linear; $1.91 ; 0.45$ & 137 \\
\hline & 26 & 4 & Log-linear; $1.47 ; 0.32$ & 95 \\
\hline & 26 & 5.8 & Log-linear; $1.37 ; 0.27$ & 81 \\
\hline & 26 & 8 & Log-linear; $1.29 ; 0.22$ & 66 \\
\hline & 26 & 10 & Log-linear; $1.23 ; 0.18$ & 57 \\
\hline & 36 & 4 & Log-linear; $1.59 ; 0.37$ & 109 \\
\hline
\end{tabular}


Table 3 (continued)

\begin{tabular}{|c|c|c|c|c|}
\hline Health case categories & $\begin{array}{l}X^{\mathrm{a}} \\
\left(\mu \mathrm{g} / \mathrm{m}^{3} \mathrm{PM}_{2.5}\right)\end{array}$ & $\begin{array}{l}X_{o}^{\mathrm{a}} \\
\left(\mu \mathrm{g} / \mathrm{m}^{3} \mathrm{PM}_{2.5}\right)\end{array}$ & $\begin{array}{l}\text { Shape of exposure function, } \\
\mathrm{RR} \text { and attributable fraction for } \mathrm{PM}_{2.5}\end{array}$ & $\begin{array}{l}\text { Number of deaths from } \\
\text { exposure to } \mathrm{PM}_{2.5} \text { for all ages }\end{array}$ \\
\hline & 16 & 4 & Log-linear; $1.31 ; 0.23$ & 70 \\
\hline & 52 & 4 & Log-linear; $1.72 ; 0.42$ & 124 \\
\hline
\end{tabular}

${ }^{\mathrm{a}} X$ is the observed concentration of $\mathrm{PM}_{2.5}$ (in $\mu \mathrm{g} / \mathrm{m}^{3}$ ) and $X_{o}$ is the background concentration $\left(\mu \mathrm{g} / \mathrm{m}^{3}\right.$, as the lowest effect level)

${ }^{\mathrm{b}}$ The suggested $\beta$ coefficients for measuring cardiovascular case and lung cancer case in the linear exposure function approach are 0.00893 and 0.01267 , respectively, based on Ostro (2004)

Open Access This article is distributed under the terms of the Creative Commons Attribution 4.0 International License (http:// creativecommons.org/licenses/by/4.0/), which permits unrestricted use, distribution, and reproduction in any medium, provided you give appropriate credit to the original author(s) and the source, provide a link to the Creative Commons license, and indicate if changes were made.

\section{References}

Atwood EC, Englhart S, Lorenz E, Halle W, Wiedemann W, Siegert F (2016) Detection and characterization of low temperature peat fires during the 2015 fire catastrophe in Indonesia using a new highsensitivity fire monitoring satellite sensor (FireBird). PLoS ONE 11(8):e0159410. https://doi.org/10.1371/journal.pone.0159410

Benjamin PYHL, Zoe GD, Matthew JS (2017) Smoke pollution disrupted biodiversity during the 2015 El Niño fires in Southeast Asia. Environ Res Lett 12(9):094022. https://doi.org/10.1088/17489326/aa87ed

BNPB Indonesia (Badan Nasional Penanggulangan Bencana Indonesia) (2017) Data Informasi Bencana Indonesia: Kebakaran Hutan dan Lahan di Provinsi Kalimantan Tengah Tahun 2015. Available online: http://bnpb.cloud/dibi/tabel1b (Accessed on 19 September 2018)

BPS Central Kalimantan (2016) Provinsi Kalimantan Tengah Dalam Angka Kalimantan Tengah Province in Figures 2016. BPS Statistics (Badan Pusat Statistik) of Kalimantan Tengah Province. Palangka Raya Available online: https://kalteng.bps.go.id/ publication/2016/07/15/8c86b2a27099d5760635d2b0/provinsikalimantan-tengah-dalam-angka-2016.html (Accessed on 11 July 2017)

BPS Central Kalimantan (2017) CDR crude death rate 2015 in Parameter Hasil Proyeksi Penduduk Kalimantan Tengah 2010-2035. BPS Statistics (Badan Pusat Statistik) of Kalimantan Tengah Province. Palangka Raya. Available online: https://kalteng.bps.go.id/ statictable/2017/04/27/409/parameter-hasil-proyeksi-pendudukkalimantan-tengah-tahun-2010-2035.html (Accessed on 31 May 2019)

Burnett RT, Pope CA III, Ezzati M, Olives C, Lim SS, Mehta S, Anderson HR (2014) An integrated risk function for estimating the global burden of disease attributable to ambient fine particulate matter exposure. Environ Health Perspect 122(4):397-403. https://doi.org/10. 1289/ehp.1307049

Burnett R, Chen H, Szyszkowicz M, Fann N, Hubbell B, Pope CA III, Apte JS, Brauer M, Cohen A, Weichenthal S, Coggins J, Di Q, Brunekreef B, Frostad J, Lim SS, Kan H, Walker KD, Thurston GD, Hayes RB, Lim CC, Turner MC, Jerrett M, Krewski D, Gapstur SM, Diver WR, Ostro B, Goldberg D, Crouse DL, Martin
RV, Peters P, Pinault L, Tjepkema M, Donkelaar A, Villeneuve PJ, Miller AB, Yin P, Zhou M, Wang L, Janssen NAH, Marra M, Atkinson RW, Tsang H, Thach TQ, Cannon JB, Allen RT, Hart JE, Laden F, Cesaroni G, Forastiere F, Weinmayr G, Jaensch A, Nagel G, Concin H, Spadaro JV (2018) Global estimates of mortality associated with long-term exposure to outdoor fine particulate matter. Proc Natl Acad Sci 115(38):9592-9597. https://doi.org/10. 1073/pnas. 1803222115

Carmenta R, Zabala A, Daeli W, Phelps J (2017) Perceptions across scales of governance and the Indonesian peatland fires. Glob Environ Chang 46:50-59. https://doi.org/10.1016/j.gloenvcha. 2017.08.001

Crippa P, Castruccio S, Archer-Nicholls S, Lebron GB, Kuwata M, Thota A, Sumin S, Butt E, Wiedinmyer C, Spracklen DV (2016) Population exposure to hazardous air quality due to the 2015 fires in Equatorial Asia. Sci Rep 6:37074. https://doi.org/10.1038/ srep37074

Dinas Kesehatan Provinsi Kalimantan Tengah (2016) Profil Kesehatan 2015 Provinsi Kalimantan Tengah. Available online: http://www. depkes.go.id/resources/download/profil/PROFIL_KES PROVINSI_2015/21_KALTENG_2015.pdf (Accessed on $1 \overline{1}$ Sept 2018)

Gaveau DLA, Salim MA, Hergoualc'h K, Locatelli B, Sloan S, Wooster M, Marlier ME, Molidena E, Yaen H, DeFries R, Verchot L, Murdiyarso D, Nasi R, Holmgren P, Sheil D (2014) Major atmospheric emissions from peat fires in Southeast Asia during nondrought years: evidence from the 2013 Sumatran fires. Sci Rep 4: 6112. https://doi.org/10.1038/srep06112

Giglio L. MODIS Collection 6 Active Fire Product User's Guide Version A (2015) Department of Geographical Sciences. University of Maryland. Available online: http://modis-fire.umd.edu/pages/ manuals.php (Accessed on 25 July 2016)

Godłowska J, Hajto MJ, Tomaszewska AM (2015) Spatial analysis of air masses backward trajectories in order to identify distant sources of fine particulate matter emission. Arch Environ Prot 41:28-35. https://doi.org/10.1515/aep-2015-0015

Héroux ME, Anderson HR, Atkinson R, Brunekreef B, Cohen A, Forastiere F, Hurley F, Katsouyanni K, Krzyzanowski DK, Künzli N, Mills I, Querol X, Ostro B, Walton H (2015) Quantifying the health impacts of ambient air pollutants: recommendations of a WHO/Europe project. Int J Public Health 60(5):619-627. https:// doi.org/10.1007/s00038-015-0690-y

Hirano T, Segah H, Kusin K, Limin S, Takahashi H, Osaki M (2012) Effects of disturbances on the carbon balance of tropical peat swamp forests. Glob Chang Biol 18:3410-3422. https://doi.org/10.1111/j. 1365-2486.2012.02793.x

Hoek G, Krishnan RM, Beelen R, Peters A, Ostro B, Brunekreef B, Kaufman JD (2013) Long-term air pollution exposure and cardiorespiratory mortality: a review. Environ Health 12:43. https://doi. org/10.1186/1476-069X-12-43 
Huijnen V, Wooster MJ, Kaiser JW, Gaveau DLA, Flemming J, Parrington M, Inness A, Murdiyarso D, Main B, van Weele M (2016) Fire carbon emissions over maritime southeast Asia in 2015 largest since 1997. Sci Rep 6:26886. https://doi.org/10.1038/ srep26886

IHME-GHDx (2018) Institute for Health Metrics and Evaluation (IHME) - Global Health Data Exchange (GHDx): Global Burden of Disease Study 2017 (GBD 2017) Results. Global Burden of Disease Collaborative Network. Seattle, United States. Available from http://ghdx.healthdata.org/gbd-results-tool (Accessed on 20 May 2019)

INCAS (2016) Indonesian National Carbon Accounting System. Available online: http://www.incas-indonesia.org/data/centralkalimantan/ (Accessed on 14 Feb 2017).

Khairullah, Effendy S, Makmur EES (2017) Trajectory and concentration PM 10 on forest and vegetation peat-fire HYSPLIT model outputs and observations (period: September - October 2015). IOP Conf Ser Earth Environ Sci 58(1):012038. https://doi.org/10.1088/17551315/58/1/012038

Koplitz SN, Mickley LJ, Marlier ME, Buonocore JJ, Kim PS, Liu T, Sulprizio MP, DeFries RS, Jacob DJ, Pongsiri M, Myers SS, Schwartz J (2016) Public health impacts of the severe haze in Equatorial Asia in September-October 2015: Demonstration of a new framework for informing fire management strategies to reduce downwind smoke exposure. Environ Res Lett 11(9). https://doi.org/ 10.1088/1748-9326/11/9/094023

Lohberger S, Stängel M, Atwood EC, Siegert F (2018) Spatial evaluation of Indonesia's 2015 fire-affected area and estimated carbon emissions using Sentinel-1. Glob Chang Biol 24(2):644-654. https://doi. org/10.1111/gcb.13841

Marlier ME, DeFries RS, Kim PS, Koplitz SN, Jacob DJ, Mickley LJ, Myers SS (2015) Fire emissions and regional air quality impacts from fires in oil palm, timber, and logging concessions in Indonesia. Environ Res Lett 10(8):085005. https://doi.org/10.1088/ 1748-9326/10/8/085005

Miettinen J, Shi C, Liew SC (2016) Land cover distribution in the peatlands of Peninsular Malaysia, Sumatra and Borneo in 2015 with changes since 1990. Glob Ecol Conserv 6:67-78. https://doi.org/10. 1016/j.gecco.2016.02.004

Miettinen J, Hooijer A, Vernimmen R, Liew SC, Page SE (2017) From carbon sink to carbon source: Extensive peat oxidation in insular Southeast Asia since 1990. Environ Res Lett 12(2017):024014. https://doi.org/10.1088/1748-9326/aa5b6f

MoEFRI (Ministry of Environment and Forestry Republic of Indonesia) (2015) Sipongi: Karhutla Monitoring Sistem. Ministry of Environment and Forestry Republic of Indonesia. Jakarta, Indonesia. Available online: http://sipongi.menlhk.go.id/peta/ hotspot provinsi (Accessed on 26 Oct 2016)

MoFRI (Ministry of Forestry Republic of Indonesia) (2014) Land cover maps. Ministry of Forestry Republic of Indonesia. Jakarta, Indonesia. Available online: http://webgis.menlhk.go.id:8080/pl/pl. $\mathrm{htm}$ (Accessed on $14 \mathrm{Feb} 2015)$

Ostro B (2004) Outdoor air pollution: assessing the environmental burden of disease at national and local levels. Environmental Burden of Disease Series, No. 5 (Prüss-Üstün A, Campbell-Lendrum, D, Corvalán C, Woodward A, eds). Geneva: World Health Organization. Available: https://www.who.int/quantifying ehimpacts/publications/ebd5.pdf (accessed 31 May 2019).

Pope CAIII, Dockery DW (1999) Epidemiology of particle effects. In: Holgate ST, Samet JM, Koren HS, Maynard RL (eds) Air pollution and health. Academic Press, London, pp 673-705
Pope CA III, Burnett RT, Thun MJ, Calle EE, Krewski D, Ito K, Thurston GD (2002) Lung cancer, cardiopulmonary mortality, and long-term exposure to fine particulate air pollution. JAMA 287(9):1132-1141. https://doi.org/10.1001/jama.287.9.1132

Ritung S, Wahyunto, Nugroho K, Sukarman, Hikmatullah, Suparto CT (2011) Peta lahan gambut Indonesia. Skala 1:250.000 (Maps of Peatland Distribution in Indonesia). Balai Besar Sumber Daya Lahan Pertanian (BBSDLP) Ministry of Agriculture, Republic of Indonesia

Ruchi S, Rajasekhar B (2017) Indoor human exposure to sizefractionated aerosols during the 2015 Southeast Asian smoke haze and assessment of exposure mitigation strategies. Environ Res Lett 12(11):114026. https://doi.org/10.1088/1748-9326/aa86dd

Stein AF, Draxler RR, Rolph GD, Stunder BJB, Cohen MD, Ngan F (2015) NOAA's HYSPLIT atmospheric transport and dispersion modelling system. Bull Am Meteorol Soc 96:2059-2077. https:// doi.org/10.1175/BAMS-D-14-00110.1

Stockwell CE, Jayarathne T, Cochrane MA, Ryan KC, Putra EI, Saharjo BH, Nurhayati AD, Albar I, Blake DR, Simpson IJ, Stone EA, Yokelson RJ (2016) Field measurements of trace gases and aerosols emitted by peat fires in Central Kalimantan, Indonesia during the 2015 El Niño. Atmos Chem Phys 16(18):11711-11732. https://doi. org/10.5194/acp-2016-411

Sumarga E (2017) Spatial indicators for human activities may explain the 2015 fire hotspot distribution in Central Kalimantan Indonesia. Ecol Soc 21(2):52. https://doi.org/10.5751/ES-08490-210252

Tacconi L (2016) Preventing fires and haze in Southeast Asia. Nat Clim Chang 6:640-643. https://doi.org/10.1038/nclimate3008

The Indonesian Ministry of Health (2015) Health problems caused by smoke haze from the 2015 forest and peat fires. Available online: http://www.depkes.go.id/resources/download/pusdatin/infodatin/ infodatin-asap.pdf http://www.depkes.go.id/resources/download/ pusdatin/infodatin/ http://www.pusdatin.kemkes.go.id/ folder/view/ 01/structure-publikasi-pusdatin-info-datin.html (Accessed on 8 Aug 2016)

The Indonesian Ministry of Health (2016) Indonesia health profile 2015: Profil Kesehatan Indonesia 2015. Available online: http://www. depkes.go.id/resources/download/pusdatin/profil-kesehatanindonesia/profil-kesehatan-Indonesia-2015.pdf (Accessed on 8 Aug 2017)

The Indonesian National Institute of Aeronautics and Space (2015) The estimate of the Indonesian burnt areas in the period 1 July -20 October 2015. Available online: https://www.lapan.go.id/index. php/subblog/read/ 2015/2052/LAPANPerkirakan-Luas-danSebaran-Daerah-Terbakar-di-Indonesia. http://pusfatja.lapan.go.id/ files_uploads_ebook/publikasi/Panduan_hotspot_2016\% 20versi $\%$ 20draft\%201_LAPAN.pdf. (Accessed on 8 Aug 2016)

Turetsky MR, Benscoter B, Page S, Rein G, van der Werf GR, Watts A (2015) Global vulnerability of peatlands to fire and carbon loss. Nat Geosci 8(1):11-14. https://doi.org/10.1038/ngeo2325

Uda SK, Hein L, Sumarga E (2017) Towards sustainable management of Indonesian tropical peatlands. Wetl Ecol Manag 25(6):683-701. https://doi.org/10.1007/s11273-017-9544-0

Uda SK, Schouten G, Hein L (2018) The institutional fit of peatland governance in Indonesia. Land Use Policy Elsevier Ltd. https:// doi.org/10.1016/j.landusepol.2018.03.031

WHO Regional Office for Europe (2016) Health risk assessment of air pollution - general principles. Copenhagen. Available online http:// www.euro.who.int/_data/assets/pdf_file/0006/298482/Health-riskassessment-air-pollution-General-principles-en.pdf?ua=1 (Accessed on 27 Mar 2019). 
WHO World Health Organization (2006) Air quality guidelines for particulate matter, ozone, nitrogen dioxide and sulfur dioxide - Global update 2005 - Summary of risk assessment. Environ Sci Pollut Res 3(91):23-23. https://doi.org/10.1007/BF02986808 Available online: http://apps.who.int/iris/bitstream/10665/69477/1/WHO SDE_PHE_OEH_06.02_eng.pdf (Accessed on 8 Aug 2017)

WHO World Health Organization (2013) Health effects of particulate matter: policy implications for countries in eastern Europe, Caucasus and central Asia. Available online: http://www.euro.who. int/ data/assets/pdf file/ 0006/189051/Health-effects-ofparticulate-matter-final-Eng.pdf (Accessed on $14 \mathrm{Feb} 2017$ )

WHO World Health Organization (2014) Ambient Air Pollution Database 2014. Available online: http://www. who.int/quantifying_ehimpacts/
national/.../AAP_PM_database_May2014.xls (Accessed on 27 January 2018)

World Bank (2016) The cost of fire : an economic analysis of Indonesia's 2015 fire crisis. Indonesia sustainable landscapes knowledge. Note no. 1. Washington, D.C. World Bank Group. Available online: http://pubdocs.worldbank.org/en/643781465442350600/Indonesiaforest-fire-notes.pdf. (Accessed on 8 Aug 2017)

Publisher's note Springer Nature remains neutral with regard to jurisdictional claims in published maps and institutional affiliations. 